\title{
Psychiatric Care For A Person With MELAS Syndrome: A Case Report
}

\author{
Douglas Yeung Leong ${ }^{1}$, Rei Yen Chee ${ }^{1}$, and Yit Shiang Lui ${ }^{1}$ \\ ${ }^{1}$ National University Hospital
}

February 4, 2021

\begin{abstract}
A patient with diagnosed MELAS (mitochondrial encephalomyopathy, lactic acidosis and stroke-like episodes) syndrome had developed psychological and behavioural disturbances at a later stage of his illness. Psychiatric care for this patient would not be possible without a multidisciplinary team approach involving multi-prong interventions from the different team members.
\end{abstract}

\section{Hosted file}

MELAS_CCR(Non-anonymised)_AMA_edited.pdf available at https://authorea.com/users/393750/ articles/507315-psychiatric-care-for-a-person-with-melas-syndrome-a-case-report

Hosted file

MELAS_CCR_FIGURES.pdf available at https://authorea.com/users/393750/articles/507315psychiatric-care-for-a-person-with-melas-syndrome-a-case-report 